\title{
Glaciochemistry and pigment producing ability of bacteria from roof of the world, the glaciers of Karakoram, Pakistan
}

Noor Hassan ( $\nabla$ noorhassan672@gmail.com )

Quaid-i-Azam University https://orcid.org/0000-0002-6619-6806

Muhammad Rafiq

Balochistan University of Information Technology and Management Sciences

Abdul Haleem

Quaid-i-Azam University

Aamir Ali Shah

Quaid-i-Azam University

Fariha Hasan

Quaid-i-Azam University

\section{Research Article}

Keywords: Bacterial diversity, carotenoid pigments, geochemistry, glaciers, Karakoram

Posted Date: March 4th, 2021

DOI: https://doi.org/10.21203/rs.3.rs-271782/v1

License: (9) This work is licensed under a Creative Commons Attribution 4.0 International License. Read Full License 


\section{Abstract}

The Karakoram Mountain Range (KMR) is one of the largest mountain ranges in the world, with $~ 37 \%$ of its area glaciated. Here, we present the geochemistry of ice, sediment and meltwaters sampled from Ghulmet, Ghulkin and Hopar glaciers of the Karakoram Range, Pakistan, in addition to the first information on the diversity of pigmented bacteria evaluated using culture-dependent techniques. Geochemical analyses revealed $\mathrm{Ca}^{2+}$ and $\mathrm{SO}_{4}{ }^{2-}$ to be the most abundant cation and anion species across all glacial samples, respectively. Total organic carbon (TOC), total nitrogen (TN) and total phosphorus (TP) were found in the sediments of all glaciers studied in current research. Bacterial species were capable of producing a variety of different pigments, including alloxanthin, astaxanthin, bacterioruberin, $\beta$-carotene, 19'-hexanoyloxyfucoxanthin, peridinin, violacein and zeaxanthin. Culturable bacterial diversity was studied using two molecular biomarkers, 16S rRNA and rpoB gene, with a total of 82 bacterial strains representing 25 genera identified across all glacial samples. This study provides the first characterization of glacier-associated, pigment-producing bacterial communities from the KMR. Findings are important for considerations of alternative sources of conventional pigment production in industrial fields.

\section{Introduction}

Around 15 million $\mathrm{km}^{2}(10 \%)$ of the Earth's surface is covered by glaciers and ice sheets which are characterized by low temperatures (Anesio and Laybourn-Parry 2012; Stibal et al. 2015), which are characterized by low temperatures. In recent times, glaciers and ice sheets have been identified as a biome harboring microorganism that contribute to important biogeochemical processes globally (Hodson et al. 2008; Anesio and Laybourn-Parry 2012). Based on the study of Castello and Rogers (2005), glacier melt releases approximately $1 \times 10^{17}$ to $1 \times 10^{21}$ viable microbes at the global scale annually. Glaciers become habitable during summers as water availability leads to occurrence of microflora in various habitats including snow, ice, biofilms and cryoconite holes (Lutz et al. 2016). Among these habitats, cryoconite holes have been the most widely investigated habitat up to now (Edwards et al. 2014). They are formed on glacial surfaces because of melting of inorganic and organic debris into ice driven by solar radiation (Anesio et al. 2009).

Extremophiles existence has been observed in almost all ice phases described from glacial environments (Priscu and Christner 2004; Rafiq 2016, 2020, 2021), such as atmospheric particles (Sattler et al. 2001), snow (Takeuchi et al. 1998), glacier ice (Priscu et al. 2006), accretion ice (Priscu et al. 2006), glacial sediments (Hassan et al. 2017, 2018, 2020a) and basal ice/till mixtures (Skidmore et al. 2000; Foght et al. 2004). Pressure, solar radiation, rock-water contact, $\mathrm{pH}$, ionic strength, reduction potential, moisture and nutrient content are some of the parameters that may differ immensely in supraglacial, englacial, and subglacial environments (Hodson et al. 2017). Such variety of abiotic conditions characteristic of glacial environments likely provides a wealth of niches inhabitable by a diversity of microorganisms. A combination of adaptation strategies for cellular metabolism has been observed in these organisms 
(Cavicchioli et al. 2002), such as production of cold active enzymes, antifreeze proteins and exopolymeric substances to cope with cold tolerance (Siddiqui and Cavicchioli 2006; Hassan et al. 2016). Cell membrane fluidity and integrity is vital for membrane functions at low temperatures (Hassan et al. 2020b). It is known from previous studies that organisms cope with cold conditions by decreasing the average fatty acid chain length and increasing the proportion of unsaturated fatty acids, which leads toward the maintenance of cell membrane fluidity (Anesio et al. 2009: Hassan et al. 2016).

In addition, cold habitats with high elevation, are exposed to higher solar radiation especially between 280 and $400 \mathrm{~nm}$ (UV radiation) (Rothschild 1999). Increased UV radiation has extreme detrimental effects on microbial life inhabiting cold environments by directly damaging DNA, RNA, proteins, enzymes and lipids (Cockell and Knowland 1999; Rothschild 1999). Detrimental impacts of UV radiation can be evident following direct absorption by biomolecules or via indirect mechanisms, for example, by stimulating the production of reactive oxygen species (ROS) that ultimately cause oxidation of essential cell components (Moline et al. 2013). Accordingly, microbial adaptations have evolved in order to minimize such effects, including pigment production (Libkind et al. 2009). The higher occurrence of pigment production observed in bacteria isolated from ice cores, glaciers and marine surface waters (Foght et al. 2004; Agogue et al. 2005; Zhang et al. 2008) suggests a potential role for pigmentation in bacteria related to adaptation against UV radiation in cold habitats. Most importantly, carotenoid pigments have been found to modulate fluidity of cell membrane in bacteria residing cold environments by UV radiation (Cockell and Knowland 1999; Jagannadham et al. 2000). In addition, studies also reported carotenoid pigments as a protective tool for phytoplankton and non-photosynthetic bacteria in low temperature against UV radiation (Cockell and Knowland 1999).

Bacterial diversity in polar and non-polar habitats across the Arctic (Bottos et al. 2008; Hell et al. 2012), Antarctica (Yergeau et al. 2007; Niederberger et al. 2008) and Himalayas (Pradhan et al. 2010) has been previously examined using culture-dependent and -independent techniques. In addition, glaciers located in non-polar habitats most famously of the Hindu Kush, Karakoram and Himalaya (HKKH) mountain range, have also been studied for the presence of bacterial populations (Branda et al. 2010; Gupta et al. 2015; Rafiq et al. 2017, 2019). Many researchers reported occurrence of bacteria, for example, Exiguobacterium indicum (Chaturvedi et al. 2006), Dyadobacter hamtensis (Chaturvedi et al. 2005), Leifsonia pindariensis, Bacillus cecembensis (Reddy et al. 2008), Cryobacterium roopkundense (Reddy et al. 2009), Cryobacterium pindariense (Reddy et al. 2010), Paenibacillus glacialis (Kishore et al. 2010) and Serratia Marcescens (Hassan et al. 2019) from various samples of glacial soil, snow, water and sediments. The main purpose of the current research work was to study geochemical properties of glacial samples which were not studied before and the culturable diversity of pyschrotolerant bacteria from glaciers of Karakoram Mountain range, Pakistan, for the first time. Moreover, these bacteria were studied for pigments production and analyzed for the effects of temperature on selected pigments production.

\section{Material And Methods}

\section{Sampling sites and processing}


Three different glaciers, named Ghulmet glacier $\left(36^{\circ} 12.474 \mathrm{~N}, 74^{\circ} 29.035 \mathrm{E}\right)$, Hopar (Bualtar) glacier (36.2108228 N, 74.7724664 E) and Ghulkin glacier (36.42791 N, 74.80659 E), located in the Karakorum Mountain Rang, Pakistan, were selected for this study (Fig. 1). Hopar glacier, also known as Baultar glacier, is positioned between two highest peaks, Diran peak (7257 m high) and Miyar peak (6824 m high), Hunza valley, Karakorum Mountains Range, Pakistan. Its total length is $18 \mathrm{~km}$. In addition, Ghulkin glacier is located in Gojal, one of the biggest counties of the Gilgit-Baltistan, Pakistan. Its name is derived from two local Wakhi words, 'Ghulk', meaning 'well' and 'kin', meaning 'whose'. It starts from the Ultar Sar (north-eastern part).

Glacial ice, sediments and meltwater were sampled aseptically from each glacier. Approximately 300-400 $\mathrm{g}$ sediments were collected using sterilized gloves and scoops to avoid sample contamination. Individual samples were immediately placed into sterile Whirl-pack bags (Nasco, Fort Atkinson, WI) (for sediments) and sterilized polyethylene bottles (for ice samples). Temperature using Easy-Read thermometer (Sigma Aldrich) was recorded at the time of sampling (Table 1). All samples were transported on ice to the Department of Microbiology, Quaid-i-Azam University, Islamabad and stored at $-20^{\circ} \mathrm{C}$ for subsequent analyses.

\section{Determination of TOC, TN, TP and major ions content}

Concentrations of major anions $\left(\mathrm{Cl}^{-}\right.$and $\left.\mathrm{SO}_{4}{ }^{2-}\right)$ and cations $\left(\mathrm{Ca}^{2+}, \mathrm{K}^{+}, \mathrm{Mg}^{2+}, \mathrm{Na}^{+}\right.$and $\left.\mathrm{NH}_{4}^{+}\right)$were conducted in all samples using a Dionex ICS-5000 (Thermo Scientific), while $\mathrm{NH}_{3}, \mathrm{NO}_{3}{ }^{-}$and $\mathrm{PO}_{4}{ }^{2-}$ were analyzed using a Gallery Plus automated photometric analyzer (Thermo Scientific). Water and ice after melting, were filtered prior all analyses processes. Specific retention times (40 min), an eluent gradient $\left(\mathrm{KOH}, \mathrm{MSA}, \mathrm{K}_{2} \mathrm{CO}_{3}\right.$, and $\left.\mathrm{LiOH}\right)$ as well as a limit of detection between 0.05-10 ppm were used for detection of ions (Rafiq et al. 2019). In addition, for sediment analysis, sediment was digested using aqua-regia ( $\mathrm{HCl}$ : $\mathrm{HNO} 3=3: 1$ ) method (Rafiq et al. 2019). Briefly, $15 \mathrm{~mL}$ aqua-regia reagent was mixed with $1 \mathrm{~g}$ of sediment and allowed to heating at $150^{\circ} \mathrm{C}$. After appearance of brown fumes, $3 \mathrm{~mL}$ of $5 \%$ hypochloric acid were added and kept again at $150^{\circ} \mathrm{C}$. Once the white fumes were appeared, mixture was finally filtered and diluted using double deionized water.

Total organic carbon (TOC) and total nitrogen (TN) were measured through FlastEA 1112 nitrogen and carbon elemental analyzer following procedure proposed by Hedges and Stern (1984), whereas, total phosphorus (TP) was determined according the protocol described by Koroleff (1976). Briefly, for TP analysis, samples were added into a solution of oxidizing reagent ( $\mathrm{g} / \mathrm{L}: 50 \mathrm{~g}$ potassium peroxodisulphate, $30 \mathrm{~g}$ boric acid and $15 \mathrm{~g}$ sodium hydroxide) and autoclaved at $121^{\circ} \mathrm{C}$ for 30 minutes and then analyzed by gallery ${ }^{\text {TM }}$ plus automated photometric analyzer (Thermo Scientific). Prior to autoclaving, ratio of oxidizing reagent and samples was adjusted as 5:50, respectively. For TN and TOC analysis, $0.1 \mathrm{~g}$ of sediment was mixed with $2 \mathrm{ml}$ of $1 \mathrm{M} \mathrm{HCL}$, agitated for 5 min using ultrasonic agitator and the dried at $50^{\circ} \mathrm{C}$ for $12 \mathrm{hrs}$. Lastly, dried samples were shifted to tin vials for analysis.

\section{Determination of colony forming units}


Colony forming units (CFU) per $\mathrm{mL}$ or $\mathrm{g}$ for each glacial sample was determined following protocol described by Rafiq et al. (2017). Approximately $100 \mu \mathrm{L}$ of glacial ice, sediment and meltwater were taken and spread on 9 plates containing bacterial culture medium. A 1:10 ratio was adjusted by adding $1 \mathrm{~mL}$ (ice and meltwater) in sterile glass tubes containing $9 \mathrm{~mL}$ of normal saline, while $1 \mathrm{~g}$ of sediment was added in $10 \mathrm{ml}$ of sterile normal saline. 5 and $25^{\circ} \mathrm{C}$ were used for incubation of plates.

After 30 days of initial incubation, the average colony formation units (CFU/mL or g) was counted in order to determine number of culturable bacteria. Bacterial cultures displaying visually different morphologies were selected and further sub-cultured to obtain pure bacterial cultures.

\section{Culturing condition and isolation of bacterial cultures}

Isolation of bacterial cultures was carried out using Nutrient agar (NA) (g/L; D(+)-glucose 1, peptone 15, sodium chloride 6, yeast extract 3, Agar 15), Minimal salts medium (MSM) (g/L; yeast extract 3, Potassium phosphate monobasic 3 , Magnesium sulphate, anhydrous 0.12 , Calcium chloride dihydrate 0.05 , Sodium phosphate dibasic 6 , Agar 15) and Reasoner's $2 A(R 2 A)(g / L ;$ casein acid hydrolysate 0.5 , dextrose 0.5 , dipotassium phosphate 0.3 , magnesium sulfate 0.024 , protease peptone 0.5 , sodium pyruvate 0.3 , starch soluble 0.5 , yeast extract 0.5 , Agar 15 ). After initial incubation for 30 days, the distinct bacterial colonies were taken and sub-cultured using NA, R2A and MSM media. In order to examine the degree of psychrophily of isolates that were isolated at $5^{\circ} \mathrm{C}$, all bacterial isolates were grown at $25^{\circ} \mathrm{C}$ for 10 days. Bacterial isolates were preserved in $30 \%$ glycerol using Nutrient Broth (NB) (g/L; $D(+)$ glucose 1 , peptone 15 , sodium chloride 6 , yeast extract 3 ) for subsequent analyses.

\section{Molecular identification of bacterial isolates}

\section{DNA extraction and PCR amplification of target gene}

The genomic DNA of all the bacterial isolates was extracted using the Invitrogen PureLink Microbiome DNA Kit (Invitrogen) following the manufacturer's instructions. T100 Thermal Cycler (Bio-Rad Laboratories, Inc) was used to amplify target genes of all the bacterial isolates. An already prepared PCR Master Mix (2X) (Thermo Fisher Scientific). PCR Master Mix contained all PCR reagents $(0.05 \mathrm{U} / \mu \mathrm{L}$ Taq DNA polymerase, reaction buffer, $4 \mathrm{mM} \mathrm{MgCl}_{2}$, and $0.4 \mathrm{mM}$ of each dNTP) except templet DNA and primers. In brief, $10 \mu \mathrm{M}$ of each primer, $0.1 \mu \mathrm{L}$ of templet DNA (20 ng), $50 \mu \mathrm{L}$ of 2X PCR Master Mix was mixed with $50 \mu \mathrm{L}$ nuclease-free water (Thermofisher scientific) to prepare a reaction mixture of $100 \mu \mathrm{L}$ volume for amplification bacterial genes.

\section{S rRNAamplification}

16S rRNA gene of all the bacterial isolates were amplified using primers $27 \mathrm{~F}$ and 1492R (Table 2). PCR conditions used for $16 \mathrm{~S}$ rRNA amplification was adjusted as preliminary denaturation at $94^{\circ} \mathrm{C}$ for 5 min, then 40 cycles of 94,56 and $72^{\circ} \mathrm{C}$ each for $30 \mathrm{~s}$ and a final step of extension at $72^{\circ} \mathrm{C}$ for $8 \mathrm{~min}$. The amplified PCR products were confirmed via $1.2 \%(\mathrm{w} / \mathrm{v})$ agarose gel electrophoresis. 


\section{rpoB gene amplification}

Only those bacterial isolates who were not identified to the species level by 16S rRNA gene sequencing, were subjected to rpoB gene sequencing. Failure of $16 \mathrm{~S}$ rRNA gene to identify bacterial isolates at species level could be possible of its presence as multiple intragenomic copies that could lead to differences in sequences, which ultimately result in multiple ribotypes identified for a single bacterium (Case et al. 2007). Therefore, many researchers have found the RNA polymerase $\beta$-subunit (rpoB) gene sequencing as a powerful tool to identify and classify taxonomically numerous bacterial species because rpoB gene existed as a single copy in genomes of bacteria (Adekambi et al. 2009; Alvarez-Buylla et al. 2012). Amplification of rpoB gene was done using primers rpoB1698F, rpoB2041R, rpoB1531F, rpoB2760R, rpoB2491F and rpoB3554R (Table 2). The rpoB gene was amplified using PCR program set as $94^{\circ} \mathrm{C}$ for $90 \mathrm{~s}$ for initial denaturation, followed by 45 cycles of $94^{\circ} \mathrm{C}$ for $10 \mathrm{~s}, 50^{\circ} \mathrm{C}$ for $20 \mathrm{~s}$ and $72^{\circ} \mathrm{C}$ for $50 \mathrm{~s}$, as well as a final extension step at $72^{\circ} \mathrm{C}$ for $5 \mathrm{~min}$.

\section{Sequencing and phylogenetic tree analysis}

The QIAquick PCR Purification Kit (QIAGEN) was used for purification of PCR products. Purified PCR products were then sent for sequencing to MRC PPU DNA sequencing and services, University of Dundee, Scotland, UK. The resultant sequences were trimmed and filtered using BioEdit software (Hall 1999). After quality filtering, remaining sequences were subjected to BLAST (Basic Local Alignment Search Tool) (https://blast.ncbi.nlm.nih.gov/Blast.cgi) for similarity index. The most similar sequences, related to the bacterial isolates of this study, were submitted to National Center for Biotechnology Information (NCBI) for getting accession numbers.

\section{Quantitative pigment analysis}

\section{Pigment extraction}

Pigment producing bacterial isolates were grown in NB for 7 days in $250 \mathrm{~mL}$ sterile flasks and incubated at $15^{\circ} \mathrm{C}$. In addition, two isolates $\left(\mathrm{GS}_{1}\right.$ and $\left.\mathrm{GW}_{1}\right)$ were incubated at four different temperature $(5,15,25$ and $35^{\circ} \mathrm{C}$ ) in order to examine the effects of temperature on pigment production. These two isolates were able to grow well at all four temperature $\left(5,15,25\right.$ and $\left.35^{\circ} \mathrm{C}\right)$. In addition, their pigment were more intense in colors and found to cover whole petri plates as compare to others. Bacterial cultures grown on solid media, were transferred to $15 \mathrm{~mL}$ sterile falcon tubes and weighed. Before this, an empty similar falcon tube was weighed and the subtracted its weight from falcon tubes containing bacterial cultures and so on. Approximately $25 \mathrm{mg}$ of cell biomass was mixed with $5 \mathrm{~mL}$ of ice-cold acetone and vortexed for 2 $\min$. The falcon tubes were placed into chilled sonicator bath $\left(<10^{\circ} \mathrm{C}\right)$ for $20 \mathrm{~min}$. Following sonication, tubes were placed into fridge for 24 hours to allow extraction. After 24 hours, tubes were vortexed for 2 min and sonicated in chilled sonicator for $20 \mathrm{~min}$. The extracts were filtered through $0.2 \mu \mathrm{m}$ syringe filter into new $15 \mathrm{~mL}$ falcon tubes. Using a glass Pasteur pipette, $~ 1-2 \mathrm{~mL}$ of extracts were filtered into $2 \mathrm{~mL}$ amber glass screw vails (Thermo Scientific), and capped under nitrogen for storage at -20 until measurement. In parallel, $n=3$ blanks were prepared as above using extraction solvent. 


\section{High-performance liquid chromatography (HPLC) analysis}

A revised version of the HPLC method described by Van Heukelem and Thomas (2001) was used to analyze pigment extracts. An Agilent 1100 HPLC (HP, Waldbronn, Germany) equipped with photo-diode array detector (wavelength was set between 350 to $700 \mathrm{~nm}$ ), $\mathrm{C}_{8}$ column, chilled auto-sampler/injector slot with $900 \mu \mathrm{L}$ syringe head, quaternary pump with in-line vacuum degasser and thermo-statted column slot, were used for pigment analysis. Identification and quantification of analyzed pigment was carried out by considering in-line photo-diode array spectra ranging from 350 to $700 \mathrm{~nm}$ and compared with analytical standards purchased from Sigma and using $R_{t}$ (retention time). In the temperature experiment, the correlation between pigment and temperature were calculated using GraphPad Prism 5.0 software.

\section{Results}

\section{Geochemistry of glacial samples}

The measured concentrations of major ions (anions and cations) as well as TOC, TN and TP content of studied glaciers are given in (Tables 3 and 4). Sediments of all glaciers were found the most enriched for all major ions, TOC, TN and TP followed by meltwater and ice. Hopar glacier sediments showed the highest concentrations of $\mathrm{Ca}^{2+}\left(10016 \mu \mathrm{g} \mathrm{kg}^{-1}\right), \mathrm{K}^{+}\left(363 \mu \mathrm{g} \mathrm{kg}^{-1}\right), \mathrm{Mg}^{2+}\left(1081 \mu \mathrm{g} \mathrm{kg}^{-1}\right)$ and $\mathrm{PO}_{4}{ }^{2-}(0.7 \mu \mathrm{g}$ $\left.\mathrm{kg}^{-1}\right)$, whereas Ghulkin glacier sediments had the highest concentrations of $\mathrm{NO}_{3}{ }^{-}\left(248 \mathrm{\mu g} \mathrm{kg}^{-1}\right)$, and sediments of Ghulmet glacier were enriched with $\mathrm{Na}^{+}\left(1595 \mathrm{\mu g} \mathrm{kg}^{-1}\right) . \mathrm{K}^{+}$and $\mathrm{PO}_{4}{ }^{2-}$ were not detected in all glacial samples collected from Ghulmet and Ghulkin glacier, respectively. Similarly, ice sampled from Ghulmet glacier did not contain measurable amounts of $\mathrm{Mg}^{2+}$ and $\mathrm{SO}_{4}{ }^{2-}$. $\mathrm{PO}_{4}{ }^{2-}$ was not measurable in glacial ice sampled from from Hopar or Ghulmet glaciers. In addition, $\mathrm{Ca}^{2+}$ and $\mathrm{SO}_{4}{ }^{2-}$ were dominant cation and anion in all glacial samples, respectively. $\mathrm{NH}_{3}$ dominated glacial sediments, followed by water and ice. Overall, TOC was found in higher quantity in glacial samples as compared to TN and TP. The highest TOC, TN and TP were observed in sediments of all glaciers followed by meltwater and ice. TP content was below detection limits in ice from both Hopar and Ghulmet glaciers as well as in meltwater of Ghulkin glacier. TN content of glacial ice $\left(28 \mu \mathrm{g} \mathrm{g}^{-1}\right)$ was very low as compared to glacial sediments and meltwater.

\section{Molecular identification of bacterial isolates}

Bacterial isolates with their homologous bacterial species and accession numbers (16S rRNA and rpoB genes) are given in (Supplementary Tables 1, 2 and 3). In the current study, a total of 82 bacterial isolates were isolated (30 isolates from Ghulmet glacier, 30 from Hopar glacier and 22 bacterial isolates from Ghulkin glacier). All isolated bacteria belonged to 5 different bacterial phyla. Proteobacteria accounted for $66 \%$ of total bacterial isolates followed by Actinobacteria (14\% bacterial isolates), Firmicutes (10\% isolates), Deinococcus-Thermus (6\% bacterial isolates) and Bacteroidetes (4\% isolates). Forty-eight of 82 bacterial isolates were isolated from glacial sediments, 23 from glacial meltwater, and 11 from glacial 
ice. In addition, bacterial isolates $\mathrm{Gl}_{3}, \mathrm{Gl}_{4}, \mathrm{GS}_{2}, \mathrm{GS}_{3}, \mathrm{GS}_{4}, \mathrm{GS}_{12}, \mathrm{GS}_{14}, \mathrm{GW}_{2}, \mathrm{GW}_{4}, \mathrm{HI}_{2}$ and $\mathrm{HS}_{14}$ were not identifiable to the species level by $16 \mathrm{~S}$ rRNA gene sequencing and accordingly, species level rpoB gene sequencing was undertaken (Supplementary Tables 1 and 3).

\section{Quantitative pigment analysis}

An overview of quantified and identified pigments produced by bacterial isolates is listed in (Table 5). Of 37 isolates, 26 were confirmed after HPLC to produce 7 different types of pigment including alloxanthin, astaxanthin, bacterioruberin, $\beta, \beta$-carotene, $\beta, \varepsilon$-Carotene, 19'-hexanoyloxyfucoxanthin, peridinin, violacein and zeaxanthin. Fifty percentage of bacterial isolates were able to produce astaxanthin, $69 \% \beta$, $\beta$-carotene, $15 \% \beta, \varepsilon$-carotene, $26 \% 19$ '-hexanoyloxyfucoxanthin, $38 \%$ peridinin and $30 \%$ zeaxanthin. Alloxanthin was produced only by bacterial isolate $\mathrm{HS}_{8}$. Only bacterial isolate $\mathrm{GS}_{1}$ and $\mathrm{GW}_{1}$ were observed to produce bacterioruberin (138.42 $\left.\mathrm{g} \mathrm{g} \mathrm{g}^{-1}\right)$ and violacein $\left(352 \mu \mathrm{g} \mathrm{g}^{-1}\right)$, respectively. Moreover, it has been observed in quantitative analysis that xanthophylls were produced in higher quantities by bacterial isolates as compared to carotenes.

Temperature effects on pigment production by $\mathrm{GS}_{1}$ and $\mathrm{GW}_{1}$ are shown in Fig. 2. A significant reduction in pigment quantity was observed in both bacteria isolates with increasing temperature. Pigment produced by $\mathrm{GW}_{1}$ was $352 \mu \mathrm{g} \mathrm{g}^{-1}$ at $5^{\circ} \mathrm{C}$ and $81 \mu \mathrm{g} \mathrm{g}^{-1}$ at $35^{\circ} \mathrm{C}$. Similarly, a $66 \%\left(81 \mu \mathrm{g} \mathrm{g}^{-1}\right)$ reduction in pigment production was observed when bacterial isolate $\mathrm{GS}_{1}$ was grown at $35^{\circ} \mathrm{C}$, compared to $66 \%$ (352 $\mu \mathrm{g} \mathrm{g}^{-1}$ ) increase production when it was grown at $5^{\circ} \mathrm{C}$.

\section{Discussion}

The current study provides the first quantitative analysis of major anions and cations of glacial samples collected from Ghulkin, Ghulmit and Hopar glaciers situated in Karakoram Mountain Range (KMR), Pakistan. To the best of our knowledge, only Hodson et al. (2002) has examined major ions and minor elements content of meltwater originating from Batura glacier located in same KMR, Pakistan. $\mathrm{Ca}^{2+}$ was found as a major cation in all glacial samples, consistent with the findings of Hodson et al. (2002). Hasnain and Thayyen (1999) have also reported $\mathrm{Ca}^{2+}$ as a major cation from Dokriani glacier meltwaters, Himalaya. The excessiveness of $\mathrm{Ca}^{2+}$ in rocky glaciers could be the consequence of carbonate weathering coupled with one or all of following; gypsum dissolution, acid hydrolysis accompanied by sulphide oxidation or neutralization of acid aerosols containing $\mathrm{NO}_{3}{ }^{-}$and $\mathrm{SO}_{4}{ }^{2-}$ (Hodson et al. 2002). Cations $\left(\mathrm{K}^{+}, \mathrm{Na}^{+}\right.$and $\left.\mathrm{Mg}^{2+}\right)$ were observed in higher concentrations as compared to anions $\left(\mathrm{Cl}^{-}, \mathrm{PO}_{4}{ }^{2-}\right.$ and $\mathrm{SO}_{4}{ }^{2-}$ ) during the present study, from our sample locations on glaciers situated in valleys. Similar trends have also been observed by previous authors, whereby valley glaciers were also shown to contain higher quantities of cations (most importantly $\mathrm{Ca}^{2+}$ ) as compared to anions quantities (most importantly $\mathrm{SO}_{4}{ }^{2-}$ ) (Tranter et al. 1993, 1997). Interestingly, similar results with higher $\mathrm{Ca}^{2+}$ and $\mathrm{SO}_{4}{ }^{2-}$ content were also reported from glaciers located in polar regions (Fortner et al. 2005; Yde et al. 2005). 
Measurement of total organic carbon, total nitrogen and total phosphorus content of all glacial samples in the current study revealed that glacial sediments were enriched with $\mathrm{C}, \mathrm{N}$ and $\mathrm{P}$ as compare to glacial ice and water. To the best of our knowledge, no previous study has assessed the TOC, TN and TP content of glaciers located in Karakoram Mountain Range. In comparison to values reported from Arctic glacial systems (Nash et al. 2018), TOC and TN concentrations recorded here were noticeably lower (Nash et al. 2018), potentially indicating a deficit in autochthonous and/or allochthonous nutrient accumulation within KMR glacial systems as compared to polar regions (Bradley et al. 2014). However, observed values matched generally with the $C, N$ and $P$ content reported for glacier forefields (Bradley et al. 2014). At present, no information is available on potential allochthonous delivery of nutrient resources to KMR glaciers, nor the potential for autochthonous production within these systems; areas that warrant future research in order to move toward a fully developed understanding of biogeochemical cycles within these changing systems.

During the present study, bacterial isolates were identified using 16S rRNA and rpoB genes sequencing. 16S rRNA gene based identification is commonly used to detect and measure the diversity of bacteria and archaea in variety of habitats (Peixoto et al. 2002; Vos et al. 2012). However, identification of many bacterial isolates at species level were not achieved with 16S rRNA sequencing in the current study, and thus rpoB gene sequencing was employed to expand our dataset. The bacterial species isolated and identified in the present research have been reported from various cold habitats in previous studies (Prasad et al. 2013; Lutz et al. 2015; Anesio et al. 2017; Rafiq et al. 2017). Bacterial isolates were recovered dominantly from glacial sediments, which corroborates with higher nutrient levels and potentially higher temperatures as compared to glacial ice and water (Parnell et al. 2016). It is well understood that Proteobacteria predominantly exist in glacial habitats throughout the world (Xu et al. 2011; Prasad et al. 2013; Lutz et al. 2015; Anesio et al. 2017; Rafiq et al. 2017) as also observed during the present study. Bacterial communities across disparate glacial systems show analogous composition (Prasad et al. 2013; Zhang et al. 2013; Leiva et al. 2015; Cuthbertson et al. 2017; Lee et al. 2017). To the best of our knowledge, we report for the first time bacterial isolates Sphingobium xenophagum, Pseudarthrobacter scleromae and Stenotrophomonas maltophilia from any glacier located in polar or non-polar regions.

In the current work, bacterial species isolated from glacial habitats were thoroughly screened for pigment production. Quantitative identification of pigments produced by bacterial isolates revealed that a large number of isolates were able to produce various pigments including astaxanthin and $\beta$-carotene, which act as a super antioxidant by preventing ROS formation resultant from UV radiation (Asker et al. 2018). Similar pigments have been reported from many bacteria inhabiting cold habitats (Lindquist et al. 2003; Zhu et al. 2003; Hong et al. 2008; Im et al. 2008; Asker et al. 2011; Mageswari et al. 2015; Masuelli et al. 2016; Asker 2017, 2018; Kanelli et al. 2018). However, to the best of our knowledge, none of Paracoccus hibiscisoli or Paracoccus carotinifaciens has been found to produce $\beta$-carotene and zeaxanthin. In addition, $\beta$-carotene and 19'hexanoyloxyfucoxanthin have not yet been identified from Brevundimonas nasdae, Brevundimonas intermedia and Brevundimonas mediterranea but astaxanthin producing Brevundimonas vesicularis has been reported from marine habitats (Asker 2017, 2018). It is well reported 
that cold environments are exposed to higher UV radiation and detrimental effects of UVR especially with short wavelengths such as UV-B (280-320 nm) and UV-A (320-400 nm) on the microbial life inhabiting cold habitats are well documented (Jeffrey et al. 2000; Hader and Sinha 2005). To cope with the damaging effect of UVR, microbes have evolved various resistant mechanisms. Pigment production by microbial communities in cold environments is one of the strategy adapted by microbes to withstand increased UV radiation. Higher pigment production by microbial populations recovered from glaciers, ice cores and sea surfaces clearly indicates its role in adaptation to elevated UV radiation (Agogue et al. 2005; Zhang et al. 2008).

In addition, it has been observed that bacterial isolates Arthrobacter agilis $\mathrm{GS}_{1}$ and Janthinobacterium lividum $\mathrm{GW}_{1}$ ) have reduced quantity of produced pigment with raising temperature but enhanced pigments production at lower temperature. The bacterial isolate $\mathrm{GW}_{1}$ has produced high pigment at $5^{\circ} \mathrm{C}$ $\left(352 \mu \mathrm{g} \mathrm{g}^{-1}\right)$ as compare to $35^{\circ} \mathrm{C}\left(81 \mu \mathrm{g} \mathrm{g}^{-1}\right)$. Similarly, $\mathrm{GS}_{1}$ isolates also shown same pattern. These results highlight the possible role of pigment to stabilize the cytomembrane at lower temperature as cell membrane faces fluidity maintenance at reduced temperature. It has been previously linked to a relationship between increased pigment production and decreased temperature, probably related to the maintenance and increased firmness of the cytomembrane (Foght et al. 2004). UV radiation could contribute to oxidize bio-molecules within cells which associate with increased level of reactive oxygen species (ROS) that damage cell components harshly (Moline et al. 2013). Therefore, pigments have been found to protect microbial cells by neutralizing ROS. Few researchers have also suggested psychrophilic microbes that produce pigments in order to protect organelles from oxidation resultant from extreme UV radiation such as reported from the glaciers of the Tibetan Plateau (Remias et al. 2010: Boric et al. 2011). Gorton and Vogelmann (2003) reported carotenoid pigment protecting cytoplasm of Chlamydomonas nivalis from UV-B but also suggested role of integral parts of the cell in protection against UV radiation.

\section{Conclusion}

It is concluded from the current study that 82 different types of bacterial strains were isolated from Ghulmet, Hopar and Ghulkin glaciers, located in Karakorum mountain range, Pakistan. Glaciochemistry of samples showed $\mathrm{Ca}^{2+}$ and $\mathrm{SO}_{4}{ }^{2-}$ to be present in higher concentrations in all glacial samples. $16 \mathrm{~S}$ rRNA and rpoB gene sequencing revealed most of the bacterial isolates belonged to genus Pseudomonas. In addition, bacterial isolates were found to produce both types of pigments including carotenes and xanthophylls but most of bacterial isolates produced $\beta$-carotene followed by zeaxanthin. Glaciochemistry would help in future to monitor any detrimental effect of climate change on the health of glaciers located in Karakoram mountain range, Pakistan, as they are at high risk to global warming. Likewise, this research work reported bacterial diversity in glaciers with enhanced ability to produce variety of carotenoid pigments that would be an alternative to the pigments extracted from synthetic and other (e.g. plants).

\section{Declarations}




\section{Acknowledgments}

Funds for the research work was provided by Commonwealth Scholarship Commission, United Kingdom. In addition, we would like to acknowledge Dr. Simmon Cobb, Senior Teaching Laboratory Technician and Mr. James Williams, the Analytical Research Technician in LOWTEX, Bristol Glaciology Centre, School of Geographical Sciences, Faculty of Science, University of Bristol, United Kingdom, for providing technical help during research work.

\section{References}

Abyzov SS, Poglazova MN, Mitskevich IN, Ivanov MV (2005) Common features of microorganisms in ancient layers of the Antarctic ice sheet. In: Castello JD, Rogers SO (eds) Life in ancient ice. Princeton University Press, Princeton, pp 240-250

Adekambi T, Drancourt M, Raoult D (2009) The rpoB gene as a tool for clinical microbiologists. Trends Microbiol 17:37-45

Agogue H, Joux F, Obernosterer I, Lebaron PH (2005) Resistance of marine bacterioneuston to solar radiation. App Environ Microbiol 71:5282-5289

Alvarez-Buylla A, Culebras E, Picazo JJ (2012) Identification of Acinetobacter species: is Bruker biotyper MALDI-TOF mass spectrometry a good alternative to molecular techniques? Infect Genet Evol 12:345-9

Anesio AM, Hodson AJ, Fritz A, Psenner R, Sattler B (2009) High microbial activity on glaciers: importance to the global carbon cycle. Glob Change Biol 15:955-960

Anesio AM, Laybourn-Parry J (2012) Glaciers and ice sheets as a biome. Trends Ecol Evol 27:219-225

Anesio AM, Lutz S, Chrismas NAM, Benning LG (2017) The microbiome of glaciers and ice sheets. Npj Biofilms Microbiomes 10:1-11

Asker D (2017) Isolation and characterization of a novel, highly selective astaxanthin producing marine bacterium. J Agri Food Chem 65(41):9101-9109

Asker D, Awad TS, Beppu T, Ueda K (2018) Screening and profiling of natural ketocarotenoids from environmental aquatic bacterial isolates. Food Chem 253:247-254

Asker D, TS Awad, L McLandsborough, T Beppu, K Ueda (2011) Deinococcus depolymerans sp. nov., a gamma- and UV-radiation-resistant bacterium, isolated from a radioactive site in Japan. Int J Syst Evol Microbiol 61:1448-1453

Boric M, Danevcic T, Stopar D (2011) Prodigiosin from Vibrio sp. DSM 14379; a new UV-protective pigment. Microb Ecol 62:528-536 
Bottos EM, Vincent CW, Greer WF, Whyte LG (2008) Prokaryotic diversity of arctic ice shelf microbial mats. Environ Microbiol 10:950-966

Bradley JA, Singarayer JS, Anesio AM (2014) Microbial community dynamics in the forefield of glaciers. Proc R Soc B 281:20140882. http://dx.doi.org/10.1098/rspb.2014.0882

Branda E, Turchetti B, Diolaiuti G, Pecci M, Smiraglia C, Buzzini P (2010) Yeast and yeast-like diversity in the southernmost glacier of Europe (Calderone Glacier, Apennines, Italy). FEMS Microbiol Ecol 72(3):354369

Case RJ, Boucher Y, Dahllof I et al (2007) Use of 16S rRNA and rpob genes as molecular markers for microbial ecology studies. Appl Environ Microbiol 73:278-288

Cavicchioli R, Siddiqui KS, Andrews D, Sowers KR (2002) Low-temperature extremophiles and their applications. Curr Opin Biotech 13:253-261

Chaturvedi P, Reddy GSN, Shivaji S (2005) Dyadobacter hamtensis sp. nov., from Hamta glacier, located in the Himalayas, India. Int J Syst Evol Microbiol 55:2113-2117

Chaturvedi P, Shivaji S (2006) Exiguobacterium indicum sp. nov., a psychrophilic bacterium from the Hamta glacier of the Himalayan mountain ranges of India. Int J Syst Evol Microbiol 56:2765-2770

Cockell CS, Knowland J (1999) Ultraviolet radiation screening compounds. Biol Rev 74:311-345

Cuthbertson L, Amores-Arrocha H, Malard LA, Els N, Sattler B, Pearce DA (2017) Characterisation of Arctic bacterial communities in the air above Svalbard. Biol (Basel) 6(2):29.

https://doi.org/10.3390/biology6020029

Edwards A, Mur LA, Girdwood SE et al (2014) Coupled cryoconite ecosystem structure-function relationships are revealed by comparing bacterial communities in alpine and Arctic glaciers. FEMS Microbiol Ecol 89:222-237

Foght J, Aislabie J, Turner S, Brown CE, Ryburn J, Saul DJ, Lawson W (2004) Culturable bacteria in subglacial sediments and ice from two southern hemisphere glaciers. Microbial Ecol 47:329-340

Fortner SK, M Tranter, A Fountain, WB Lyons, KA Welch (2005) The geochemistry of supraglacial streams of Canada Glacier, Taylor Valley (Antarctica) and their evolution into proglacial waters. Aquat Geochem $11: 391-412$

Gorton HL, Vogelmann TC (2003) Ultraviolet radiation and the snow alga Chlamydomonas nivalis (Bauer) Wille. Photochem Photobiol 77:608-615

Gupta P, Sangwan N, Lal R, Vakhlu J (2015) Bacterial diversity of Drass, cold desert in Western Himalaya, and its comparison with Antarctic and Arctic. Arch Microbiol 197(6):851-860 
Hader DP, Sinha RP (2005) Solar ultraviolet radiation induced DNA damage in aquatic organisms: potential environmental impact. Mutat Res 571:221-233

Hasnain SI, Thayyen RJ (1999) Controls on the major-ion chemistry of the Dokriani glacier meltwaters, Ganga Basin, Garhwal Himalaya, India. J Glaciol 45:87-92

Hassan N, Anesio AM, Rafiq M, Holtvoeth J, Bull I, Haleem A, Shah AA, Hasan F (2020b) Temperature driven membrane lipid adaptation in glacial psychrophilic bacteria. Front Microbiol 11:824. https://doi.org/10.3389/fmicb.2020.00824

Hassan N, Anesio AM, Rafiq M, Holtvoeth J, Bull I, Williamson CJ, Hasan F (2020a) Cell Membrane Fatty Acid and Pigment composition of the pyschrotolerant cyanobacterium Nodularia spumigena CHS1 isolated from Hopar Glacier, Pakistan. Extremophiles 24(1):135-145

Hassan N, Hasan F, Nadeem S, Hayat M, Ali P, Khan M, Sajjad W, Zada S, Rafiq M (2018) Community analysis and characterization of fungi from Batura glacier, Karakoram mountain range. Appl Ecol Env Res 16(5):5323-5341

Hassan N, Rafiq M, Hayat M, Nadeem S, Shah AA, Hasan F (2017) Potential of psychrotrophic fungi isolated from Siachen Glacier, Pakistan, to produce antimicrobial metabolites. Appl Ecol Environ Res 15(3):1157-1171

Hassan N, Rafiq M, Hayat M, Shah AA, Hasan F (2016) Psychrophilic and Psychrotrophic Fungi: A Comprehensive Review. Rev Environ Sci Bio 15(2):147-172

Hassan N, Uddin S, Rafiq M, Rehman HU, Haleem A, Hayat M, Khan M, Jamil SSU, Hasan F (2019) Analysis of the Cell Membrane Fatty Acids and Characterization of the Psychrotolerant Serratia Marcescens HI6 isolated from Hopar (Bualtar) Glacier, Pakistan. App Ecol Environ Res 17(5):11911-11924

Hedges JI, Stern JH (1984) Carbon and nitrogen determinations of carbonate-containing solids. Limnol Oceanogr 29:657-663

Hell K, Edwards A, Zarsky J, Podmirseg SM, Girdwood S, Pachebat JA, Insam H, Sattler B (2013) The dynamic bacterial communities of a melting High Arctic glacier snowpack. The ISME J 7(9):1814-1826

Hodson A, Anesio AM, Tranter M, Fountain A, Osborn M, Priscu J, Laybourn-Parry J, Sattler B (2008) Glacial ecosystems. Ecol Monogr 78(1):41-67

Hodson A, Porter P, Lowe A, Mumford P (2002) Chemical denudation and silicate weathering in Himalayan glacier basins: Batura Glacier, Pakistan. J Hydro 262:193-208

Hodson AJ, Nowak A, Cook J, Sabacka M, Wharfe ES, Pearce DA, Convey P, Vieira G (2017) Microbes influence the biogeochemical and optical properties of maritime Anatarctic snow. J Geophys Res Biogeosci 122:1456-70 
Hong SG, Lee YK, Yim JH, Chun J, Lee HK (2008) Sanguibacter antarcticus sp. nov., isolated from Antarctic sea sand. Int J Syst Evol Microbiol 58:50-52

Im, WT, Jung H, Ten LN, Kim MK, Bora N, Goodfellow M, Lim S, Jung J, Lee S (2008) Deinococcus aquaticus sp. nov., isolated from fresh water, and Deinococcus caeni sp. nov., isolated from activated sludge. Int J Syst Evol Microbiol 58:2348-2353

Jagannadham MV, Chattopadhyay MK, Subbalakshmi C, Vairamani M, Narayanan K, Rao CM, Shivaji S (2000) Carotenoids of an Antarctic psychrotolerant bacterium, Sphingobacterium antarcticus, and a mesophilic bacterium, Sphingobacterium multivorum. Arch Microbiol 173:418-424

Jeffrey WH, Kase J, Willhelm SW (2000) Ultraviolet radiation effects on heterotrophic bacterioplankton and viruses in marine ecosystems. In: De Mora S, Demers S, Vernet M (eds) The Effects of UV Radiation in the Marine Environment. Cambridge, Cambridge University Press, pp 206-236

Kanelli M, Mandic M, Kalakona M, Vasilakos S, Kekos D, Runic JN, Topakas E (2018) Microbial Production of Violacein and Process Optimization for Dyeing Polyamide Fabrics with Acquired Antimicrobial Properties. Front Microbiol 9:1495. https://doi.org/10.3389/fmicb.2018.01495

Kishore KH, Begum Z, Pathan AA, Shivaji S (2010) Paenibacillus glacialos sp. nov., isolated from kafni glacier of Himalayas, India. Int J Syst Evol Microbiol 60(Pt 8):1909-1913

Koroleff F (1976) Determination of Nutrients. In: Grasshof E, Kremling E (eds) Methods the Seawater Analysis. Verlag Chemie Weinhein, New York, pp 126-133

Lee J, Cho YJ, Yang JY, Jung YJ, Hong SG, Kim OS (2017) Complete genome sequence of Pseudomonas antarctica PAMC 27494, a bacteriocin-producing psychrophile isolated from Antarctica. J

Biotechnol 259:15-18

Leiva S, Alvarado P, Huang Y, Wang J, Garrido I (2015) Diversity of pigmented Gram-positive bacteria associated with marine macroalgae from Antarctica. FEMS Microbiol Lett 362:fnv206. https://doi.org/10.1093/femsle/fnv206

Libkind D, Moliné M, Sampaio JP, van Broock M (2009) Yeasts from high-altitude lakes: influence of UV radiation. FEMS Microbiol Ecol 69:353-362

Lindquist D, Murrill D, Burran WP, Winans G, Janda JM, Probert W (2003) Characteristics of Massilia timonae and Massilia timonaelike isolates from human patients, with an emended description of the species. J Clin Microbiol 41:192-196

Lutz S, Anesio AM, Edwards A, Benning LG (2015) Microbial diversity on Icelandic glaciers and ice caps. Front Microbiol 6:307. http://doi.org/10.3389/fmicb.2015.00307 
Lutz S, Anesio AM, Raiswell R, Edwards A, Newton RJ, Gill F, Benning LG (2016) The biogeography of red snow microbiomes and their role in melting arctic glaciers. Nat Commun 7:11968

Mageswari A, Subramanian P, Srinivasan R, Karthikeyan S, Gothandam KM (2015) Astaxanthin from psychrotrophic Sphingomonas faeni exhibits antagonism against food-spoilage bacteria at low temperatures. Microbiol Res 179:38-44

Masuelli L, Pantanella F, La Regina G et al (2016) Violacein, an indole-derived purple-colored natural pigment produced by Janthinobacterium lividum, inhibits the growth of head and neck carcinoma cell lines both in vitro and in vivo. Tumour Biol 37:3705-3717

Moline M, Libkind D, de Garcia V, Giraudo MR (2014) Production of pigments and photo-protective compounds by cold-adapted yeasts. In: Cold-adapted Yeasts. Springer, Berlin, Heidelberg, pp 193-224

Nash MV, Anesio AM, Barker G et al (2018) Metagenomic insights into diazotrophic communities across Arctic glacier forefields. FEMS Microbiol Ecol. http://doi.org/10.1093/femsec/fiy114

Niederberger TD, McDonald IR, Hacker AL, Soo RM, Barrett JE, Wall DH, Cary SC (2008) Microbial community composition in soils of Northern Victoria Land, Antarctica. Environ Microbiol 10:1713-1724

Parnell J, McMahon S (2016) Physical and chemical controls on habitats for life in the deep subsurface beneath continents and ice. Phil Trans R Soc 374: 20140293. http://dx.doi.org/10.1098/rsta. 2014.0293

Peixoto RS, HLD Coutinho, NG Rumjanek, A Macrae, AS Rosado (2002) Use of rpoB and 16S rRNA genes to analyse bacterial diversity of a tropical soil using PCR and DGGE. Lett Appl Microbiol 35:316-320

Pradhan S, Srinivas TNR, Pindi PK, Kishore KH, Begum Z, Singh PK, Singh AK, Pratibha MS, Yasala AK, Reddy GSN, Shivaji S (2010) Bacterial biodiversity from Roopkund glacier, Himalayan mountain ranges, India. Extremophiles 14(4):377-395

Prasad S, Pratibha MS, Manasa P, Buddhi S, Begum Z, Shivaji S (2013) Diversity of Chemotactic Heterotrophic Bacteria Associated with Arctic Cyanobacteria. Curr Microbial 66:64-71

Priscu JC, BC Christner (2004) Earth's icy biosphere. In: Bull AT (ed) Microbial diversity and bioprospecting. American Society for Microbiology, Washington, D.C., USA, pp 130-145

Priscu JC, BC Christner, CM Foreman, G Royston-Bishop (2006) Biological material in ice cores. In: Elias S (ed) Encyclopedia of quaternary sciences. Elsevier, London, UK, pp 1156- 1166

Rafiq M, Hassan N, Hayat M, Ibrar M, Sajjad W, Haleem A, Maqsood-ur-Rehman M, Raza AM, Hasan F (2021). Geochemistry and Insights into the Distribution of Biotechnological Important Fungi from the Third Pole of the World, Karakoram Mountains Range. Geomicrobiology Journal.

http://doi.org/10.1080/01490451.2020.1863526

Page 15/25 
Rafiq M, Hayat M, Anesio AM et al (2017) Recovery of metallo-tolerant and antibiotic resistant psychrophilic bacteria from Siachen glacier, Pakistan. PLoS ONE 12(7): e0178180.

https://doi.org/10.1371/journal.pone.0178180

Rafiq M, Hayat M, Hassan N, Ibrar M, Haleem A, Rehman M, Ahmad F, Shah AA, Hasan F (2016) Production and characterization of antibacterial compounds by psychrotrophic Alcaligenes faecalis HTP6 isolated from Passu glacier, Pakistan Int J Biosci 8(5):122-135

Rafiq M, Hayat M, Zada S, Sajjad W, Hassan N, Hasan F (2019) Geochemistry and bacterial recovery from Hindu Kush Range glacier their potential for Metal resistance and antibiotic production. Geomicrobiol J 36(4):326-338

Rafiq M, Nadeem S, Hassan N, Hayat M, Sajjad W, Zada S, Sajjad W, Hasan F (2020) Fungal recovery and characterization from Hindu Kush mountain range, Tirich Mir glacier, and their potential for biotechnological applications. J Basic Microbiol 60(5):444-457

Reddy GSN, Prabagaran SR, Shivaji S (2008) Leifsonia pindariensis sp. nov., isolated from the Pindari glacier of the Indian Himalayas, and emended description of the genus Leifsonia. Int J Syst Evol Microbiol 58:2229-2234

Reddy GSN, Pradhan S, Manorama R, Shivaji S (2009) Cryobacterium roopkundense sp. nov., a psychrophilic bacterium from a Himalayan glacier. Int J Syst Evol Microbiol 60:866-887

Reddy GSN, Pradhan S, Manorama R, Shivaji S (2010) Cryobacterium Pindariense sp. nov., a psychrophilic bacterium from a Himalayan glacier. Int J Syst Evol Microbiol 60:866-870

Remias D, Albert A, Luetz C (2010) Effects of realistically simulated, elevated UV irradiation on photosynthesis and pigment composition of the alpine snow alga Chlamydomonas nivalis and the arctic soil alga Tetracystis sp. (Chlorophyceae). Photosynthetica 48:269-277

Rothschild LJ (1999) Microbes and radiation. In: Seckbach (ed) Enigmatic microorganisms and life in extreme environments. Kluwer Academic Publishers, Amsterdam, pp 551-562

Sattler B, Puxbaum H, Psenner R (2001) Bacterial growth in super cooled cloud droplets. Geophys Res Lett 28(2):239-242

Siddiqui KS, Cavicchioli R (2006) Cold-adapted enzymes. Annu Rev Biochem 75:403-433

Skidmore ML, JM Foght, MJ Sharp (2000) Microbial life beneath a High Arctic glacier. Appl Environ Microbiol 66:3214-3220

Stibal M, Gözdereliler E, Cameron KA, Box JE, Stevens IT, Gokul JK, Schostag M, Zarsky JD, Edwards A, Irvine-Fynn TDL, Jacobsen CS (2015) Microbial abundance in surface ice on the Greenland Ice Sheet. Front Microbiol 6:225. http://doi.org/10.3389/fmicb.2015.00225 
Takeuchi N, S Kohshima, K Fujita (1998) Snow algae community on a Himalayan glacier, Glacier AX010 East Nepal: relationship with summer mass balance. Bull Glaciol Res 16:43-50

Tranter M, Brown GH, Raiswell R, Sharp MJ, Gurnell AM (1993) A conceptual model of solute acquisition by Alpine glacial meltwaters. J Glaciol 39:573-581

Tranter M, Sharp M, Brown GH, Willis IC, Hubbard BP, Nielsen MK, Smart CC, Gordon S, Tulley M, Lamb HR (1997) Variability in the chemical composition of in-situ subglacial meltwaters. Hydrol Proc 11:59-77

Van Heukelem L, Thomas CS (2001) Computer-assisted high performance liquid chromatography method development with applications to the isolation and analysis of phytoplankton pigments. $J$ Chromatogr A 910:31-49

Vos M, Quince C, Pijl AS, de Hollander M, Kowalchuk GA (2012) A comparison of rpoB and 16S rRNA as markers in pyrosequencing studies of bacterial diversity. PLoS ONE 7: e30600.

https://doi.org/10.1371/journal.pone.0030600

Xu MS, Xin YH, Tian JS, Dong K, Yu Y, Zhang JL, Liu HC, Zhou YG (2011) Flavobacterium sinopsychrotolerans sp. nov., isolated from a glacier. Int J Syst Evol Microbiol 61:20-24

Yde JC, Knudsen NT, Nielsen OB (2005) Glacier hydrochemistry, solute provenance, and chemical denudation at a surge-type glacier in Kuannersuit Kuussuat, Disko Island, West Greenland. J Hydrol 300:172-187

Yergeau E, Newsham KK, Pearce DA, Kowalchuk GA (2007) Patterns of bacterial diversity across a range of Antarctic terrestrial habitats. Environ Microbiol 9:2670-2682

Zhang DC, Brouchkov A, Griva G, Schinner F, Margesin R (2013) Isolation and characterization of bacteria from ancient siberian permafrost sediment. Biology 2:85-106

Zhang XF, Yao TD, Tian LD, Xu SJ, An LZ (2008) Phylogenetic and physiological diversity of bacteria isolated from Puruogangri ice core. Microbial Ecol 55:476-488

Zhu F, Wang S, Zhou P (2003) Flavobacterium xinjiangense sp. nov. and Flavobacterium omnivorum sp. nov., novel psychrophiles from the China No. 1 glacier. Int J Syst Evol Microbiol 53(3):853-857

\section{Tables}

Table 1 Colony forming unit (CFU)/mL or gm and coordinates of samples 


\begin{tabular}{|c|c|c|c|c|c|c|c|}
\hline \multirow[t]{2}{*}{ Glaciers } & \multirow[t]{2}{*}{ Samples } & \multirow[t]{2}{*}{$\mathrm{pH}$} & \multirow[t]{2}{*}{$\begin{array}{l}\text { Temperatures } \\
\left.\text { ( }{ }^{\circ} \mathrm{C}\right)\end{array}$} & \multicolumn{2}{|c|}{$\begin{array}{c}\mathrm{CFU} / \mathrm{gm} \text { or } \mathrm{mL} \text { at different } \\
\text { temperatures }\end{array}$} & \multirow[t]{2}{*}{$\begin{array}{l}\text { Elevation in meters } \\
\qquad \text { (m) }\end{array}$} & \multirow[t]{2}{*}{$\begin{array}{c}\text { GPS } \\
\text { coordinates }\end{array}$} \\
\hline & & & & $5^{\circ} \mathrm{C}$ & $25^{\circ} \mathrm{C}$ & & \\
\hline \multirow[t]{2}{*}{ Ghulkin } & Sediment & 7 & 1 & $3.73 \times 10^{5}$ & $2.36 \times 10^{7}$ & 3083 & $36.42791 \mathrm{~N}$ \\
\hline & Meltwater & 7 & 1 & $3.95 \times 10^{3}$ & $3.87 \times 10^{5}$ & & $74.80659 \mathrm{E}$ \\
\hline \multirow[t]{3}{*}{ Ghulmit } & Ice & 7 & -13 & $1.34 \times 10^{2}$ & $6.50 \times 10^{4}$ & 3072 & $36^{\circ} 12.474 \mathrm{~N}$ \\
\hline & Sediment & 7 & 3 & $2.73 \times 10^{6}$ & $1.36 \times 10^{9}$ & & $74^{\circ} 29.035 \mathrm{E}$ \\
\hline & Meltwater & 7 & 1 & $4.73 \times 10^{4}$ & $2.85 \times 10^{6}$ & & \\
\hline \multirow[t]{3}{*}{ Hopar } & Ice & 7 & -12 & $3.50 \times 10^{2}$ & $7.60 \times 10^{4}$ & 2963 & $36.2108228 \mathrm{~N}$ \\
\hline & Sediment & 7 & 2 & $3.55 \times 10^{7}$ & $1.65 \times 10^{9}$ & & $74.7724664 \mathrm{E}$ \\
\hline & Meltwater & 7 & 1 & $4.50 \times 10^{3}$ & $2.65 \times 10^{6}$ & & \\
\hline
\end{tabular}

Table 2 The primers details used for the PCR amplification of 16S rRNA and rpoB genes of bacterial isolates 


\begin{tabular}{|c|c|c|c|c|}
\hline Primers & Target position $^{1}$ & Target gene & Sequence $\left(5^{\prime}-3^{\prime}\right)$ & References \\
\hline $27 F^{2}$ & $7-27$ & 16S rRNA & AGAGTTTGATCMTGGCTCAG & Paju et al. (2003) \\
\hline $1492 \mathrm{R}^{3}$ & $1492-1510$ & $16 \mathrm{~S}$ rRNA & GGTTACCTTGTTACGACTT & Paju et al. (2003) \\
\hline rpoB1698F & $1698-1715$ & гров & AACATCGGTTTGATCAAC & Dahllof et al. (2000) \\
\hline rpoB2041R & $2041-2060$ & rрoB & CGTTGCATGTTGGTACCCAT & Dahllof et al. (2000) \\
\hline rpoB1531F ${ }^{2}$ & $1531-1552$ & гров & TGGCCGAGAACCAGTTCCGCGT & Tayeb et al. (2005) \\
\hline rpoB2760R 3 & $2760-2781$ & гров & CGGCTTCGTCCAGCTTGTTCAG & Tayeb et al. (2005) \\
\hline rpoB2491F ${ }^{2}$ & $2491-2511$ & rрoB & AACCAATTCCGTATIGGTTT & Michel and Raoult (2002) \\
\hline rpoB3554R $\mathrm{R}^{3}$ & $3554-3573$ & гров & CCGTCCCA AGTCATGAAAC & Michel and Raoult (2002) \\
\hline \multicolumn{5}{|c|}{${ }^{1} \mathrm{rpoB}$ and $16 \mathrm{~S}$ nucleotides numbered used E.coli, Pseudomonas aeruginosa and Pseudomonas putida as refereno } \\
\hline & & & s direction relating to the $r R N A$. & \\
\hline
\end{tabular}

Table 3 Major ions content of glacial samples 


\begin{tabular}{|c|c|c|c|c|c|c|c|c|c|c|c|}
\hline \multirow[t]{2}{*}{ Glaciers } & \multirow[t]{2}{*}{ Samples } & \multicolumn{10}{|c|}{ Concentrations $\left(\mu \mathrm{g} \mathrm{l}^{-1} / \mathrm{kg}^{-1}\right)$} \\
\hline & & $\mathrm{Ca}^{2+}$ & $\mathrm{K}^{+}$ & $\mathrm{Mg}^{2+}$ & $\mathrm{Na}^{+}$ & $\mathrm{NH}_{4}^{+}$ & $\mathrm{Cl}^{-}$ & $\mathrm{NO}_{3}^{-}$ & $\mathrm{PO}_{4}{ }^{2-}$ & $\mathrm{SO}_{4}{ }^{2-}$ & $\mathrm{NH}_{3}$ \\
\hline \multirow[t]{3}{*}{ Hopar } & Ice & 2598 & 79 & 180 & 390 & 197 & 143 & 36 & ND & 112 & 280 \\
\hline & Sediment & 10016 & 363 & 1081 & 1015 & 378 & 28 & 145 & 0.7 & 760 & 625 \\
\hline & Meltwater & 7076 & 260 & 809 & 734 & 284 & 224 & 103 & 0.2 & 996 & 95 \\
\hline \multirow[t]{2}{*}{ Ghulkin } & Sediment & 9009 & 225 & 856 & 1324 & 464 & 76 & 248 & ND & 645 & 741 \\
\hline & Meltwater & 5008 & 204 & 707 & 946 & 308 & 100 & 81 & ND & 884 & 310 \\
\hline \multirow[t]{3}{*}{ Ghulmet } & Ice & 2257 & $\mathrm{ND}^{1}$ & ND & 441 & 221 & 121 & 58 & ND & ND & 51 \\
\hline & Sediment & 8348 & ND & 469 & 1595 & 398 & 163 & 207 & 0.5 & 558 & 569 \\
\hline & Meltwater & 6229 & ND & 929 & 990 & 271 & ND & 94 & 0.4 & 852 & 276 \\
\hline
\end{tabular}

${ }^{1}$ Not detected

Table 4 Total organic carbon, total nitrogen and total phosphorus content of glacial samples 


\begin{tabular}{|c|c|c|c|c|}
\hline \multirow[t]{2}{*}{ Glaciers } & \multirow[t]{2}{*}{ Samples } & \multicolumn{3}{|c|}{ Concentrations $\left(\mu \mathrm{g} \mathrm{ml}^{-1} / \mathrm{g}^{-1}\right)$} \\
\hline & & TOC & TN & TP \\
\hline \multirow[t]{3}{*}{ Hopar } & Ice & 486 & 57 & $\mathrm{ND}^{1}$ \\
\hline & Sediment & 7543 & 993 & 5.2 \\
\hline & Meltwater & 2771 & 125 & 3.4 \\
\hline \multirow[t]{2}{*}{ Ghulkin } & Sediment & 6897 & 1139 & 1.5 \\
\hline & Meltwater & 1799 & 101 & ND \\
\hline \multirow[t]{3}{*}{ Ghulmet } & Ice & 557 & 28 & ND \\
\hline & Sediment & 9174 & 1040 & 4.1 \\
\hline & Meltwater & 2005 & 141 & 3.8 \\
\hline${ }^{1}$ Not det & & & & \\
\hline
\end{tabular}

Table 5 An overview of quantified and identified pigments produced by bacterial isolates 


\begin{tabular}{|c|c|c|c|c|c|c|c|}
\hline \multirow[t]{2}{*}{ Isolates } & \multicolumn{7}{|c|}{ Pigments ( $\mu \mathrm{g} \mathrm{g}^{-1}$ ) } \\
\hline & Alloxanthin & Astaxanthin & $\beta$-Carotene & $\beta, \varepsilon$-Carotene & $\begin{array}{l}\text { 19'-Hexanoyloxy } \\
\text { fucoxanthin }\end{array}$ & Peridinin & Zeaxanthin \\
\hline $\mathrm{GI}_{1}$ & - & - & 4.04 & - & 8.51 & - & - \\
\hline $\mathrm{GI}_{4}$ & - & - & 7.84 & - & 11.23 & - & 2.99 \\
\hline $\mathrm{GS}_{5}$ & - & - & 4.14 & - & 110.5 & - & 9.70 \\
\hline $\mathrm{GS}_{7}$ & - & - & 12.04 & - & 350.40 & 7.45 & 10.69 \\
\hline $\mathrm{GS}_{9}$ & - & 8.13 & 191.82 & - & - & - & 30.49 \\
\hline $\mathrm{GS}_{14}$ & - & - & - & 21.32 & - & - & - \\
\hline $\mathrm{GS}_{18}$ & - & 38.43 & 4.38 & - & 61.68 & 124.03 & - \\
\hline $\mathrm{GS}_{19}$ & - & 16.87 & 29.66 & - & - & 23.91 & 24.08 \\
\hline $\mathrm{GS}_{21}$ & - & 39.59 & 2.95 & - & - & 49.05 & - \\
\hline $\mathrm{GW}_{4}$ & - & 54.45 & 5.39 & - & - & 178 & - \\
\hline $\mathrm{GW}_{7}$ & - & 31.03 & - & - & - & - & - \\
\hline $\mathrm{GW}_{8}$ & - & 140.68 & - & - & - & - & - \\
\hline $\mathrm{GW}_{9}$ & - & - & - & 101.32 & - & - & - \\
\hline $\mathrm{GhS}_{1}$ & - & 56.28 & - & - & - & - & - \\
\hline $\mathrm{GhS}_{4}$ & - & - & 2.65 & - & 34.74 & 151.54 & - \\
\hline $\mathrm{GhS}_{8}$ & - & 36.10 & 4.12 & - & - & 103.64 & - \\
\hline $\mathrm{GhW}_{6}$ & - & 21.15 & 5.64 & - & - & 312.96 & - \\
\hline $\mathrm{GhW}_{7}$ & - & 8.88 & 3.01 & - & - & 128.06 & - \\
\hline $\mathrm{HI}_{2}$ & - & - & 5.55 & - & - & - & - \\
\hline $\mathrm{HI}_{3}$ & - & - & - & 31.42 & - & - & \\
\hline
\end{tabular}




\begin{tabular}{|c|c|c|c|c|c|c|c|}
\hline $\mathrm{HS}_{3}$ & - & - & 3.17 & - & - & - & 351.67 \\
\hline $\mathrm{HS}_{8}$ & 48.46 & - & 50.77 & - & - & - & 72.01 \\
\hline $\mathrm{HS}_{14}$ & - & - & - & 10.37 & - & - & - \\
\hline $\mathrm{HS}_{16}$ & - & 14.54 & 45.03 & - & - & - & 14.12 \\
\hline $\mathrm{HW}_{5}$ & - & - & - & - & 15.49 & - & - \\
\hline $\mathrm{HW}_{6}$ & - & 6.59 & 4.14 & - & - & 108.26 & - \\
\hline
\end{tabular}

Figures 


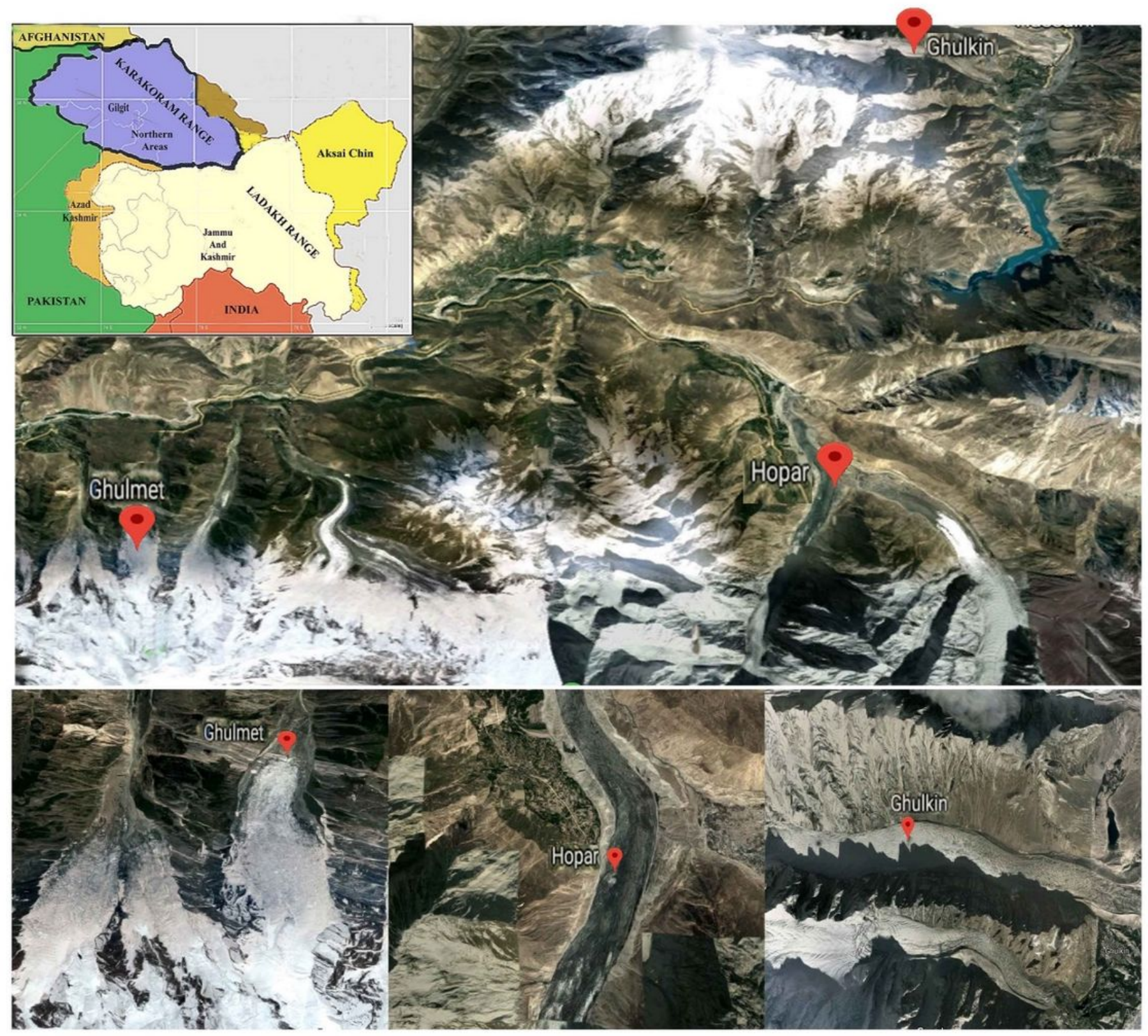

\section{Figure 1}

Topographic representation of sampling sites located in Karakoram Mountain Range, Pakistan. Note: The designations employed and the presentation of the material on this map do not imply the expression of any opinion whatsoever on the part of Research Square concerning the legal status of any country, territory, city or area or of its authorities, or concerning the delimitation of its frontiers or boundaries. This map has been provided by the authors. 


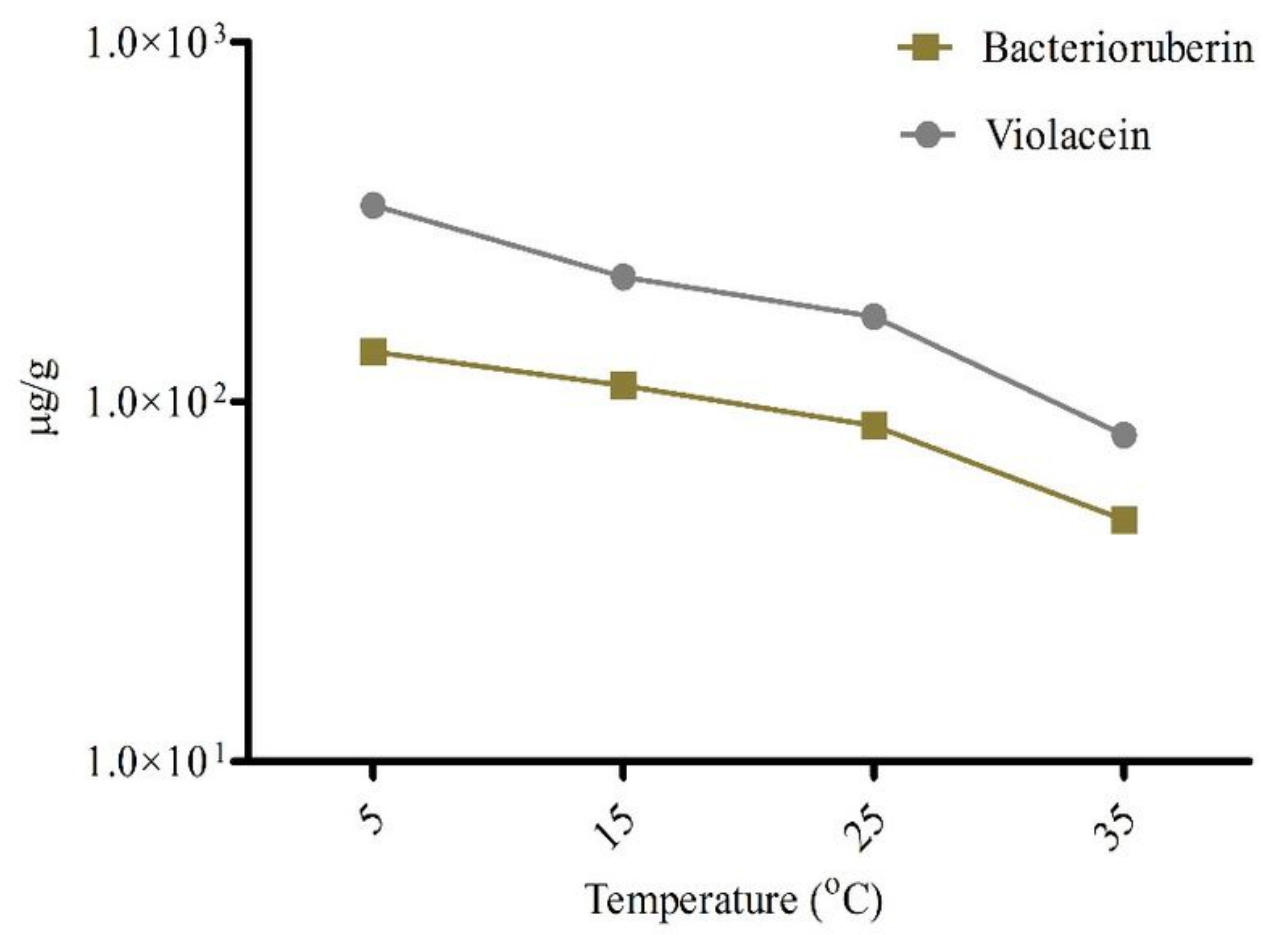

Figure 2

Pearson correlation of violacein $(r=0.980, P=0.021)$ and bacterioruberin $(r=0.979, P=0.021)$ produced by Arthrobacter agilis GS1 and Janthinobacterium lividum GW1, respectively, at different temperature

\section{Supplementary Files}

This is a list of supplementary files associated with this preprint. Click to download.

- SupplementalTable1.docx

- SupplementalTable2.docx

- SupplementalTable3.docx 